\title{
Antilisterial activity of lactic acid bacteria isolated from "Alheiras" (traditional Portuguese fermented sausages): In situ assays
}

\author{
Helena Albano, Márcia Oliveira, Ricardo Aroso, Núria Cubero, Tim Hogg, Paula Teixeira *
}

Escola Superior de Biotecnologia, Universidade Católica Portuguesa, Rua Dr. António Bernardino de Almeida, 4200-072 Porto, Portugal

Keywords: Fermented sausages; Lactic acid bacteria; Listeria; Antimicrobial activity; Bio-preservation; Bacteriocins

\begin{abstract}
A total of 226 lactic acid bacteria (LAB) isolated from "Alheira", a traditional Portuguese fermented sausage, were screened for antagonistic activity against some pathogenic microorganisms, including Listeria monocytogenes. The objective was to isolate LAB with antibacterial activity from "Alheiras" and to select strains that could be used in "Alheira" production. Isolates displaying antibacterial activity against Listeria innocua and L. monocytogenes were investigated for the nature of the antibacterial compounds active against these microorganisms. Results showed that two LAB cultures retained activity in the supernatants after neutralization and catalase treatment. These two strains were both identified as Pediococcus pentosaceus. The final aim of this work was to test the antilisterial activity of these two strains during storage of "Alheira mass" (sterilized), at $4{ }^{\circ} \mathrm{C}$. The growth of $L$. innocua population was significantly suppressed in the paste of "Alheira" when the samples were co-inoculated with the LAB strains, in comparison with the paste only inoculated with L. innocua or co-inoculated with a bacteriocin negative strain of Ped. pentosaceus (ca. $1 \times 10^{7} \mathrm{CFU} / \mathrm{g}$ after 28 days of incubation).

(C) 2007 Elsevier Ltd. All rights reserved.
\end{abstract}

Introduction

"Alheira" is a traditional, naturally fermented meat sausage typical of the Trás-os-Montes region of northern Portugal. "Alheira de Mirandela" is a highly appreciated version of this product and represents an important revenue source for this region with more than 500 ton being produced annually (http://www.idrha.min-agricultura.pt/produtos_tradicionais/estatisticas.htm). "Alheira de Mirandela" is in the process of name registration as 'Traditional Guaranteed Speciality'. The specific characteristics of the final product mainly arise from the raw materials employed, the agro-ecosystem of the area of production and the traditional technology of manufacture. "Alheira de Mirandela" is produced from chopped pork and poultry meat, lard, wheat bread, olive oil and pork fat, which are

\footnotetext{
* Corresponding author. Tel.: +351 225580001; fax: +351 225090351. E-mail address: paula@esb.ucp.pt (P. Teixeira).
}

mixed with salt, garlic and spices. The meat, lard, olive oil and spices are boiled together with water and the bread then added and the mass mixed. When everything is completely mixed the paste is stuffed into cellulose or natural pig casings and submitted to a smoking process for no longer than 8 days.

Generically the microbiology of fermented sausages is complex and the type of microflora that develops is often closely related to the ripening technique utilized. A wide variety of microorganisms have already been isolated from "Alheiras" by traditional methods. These are mainly LAB and Micrococcaceae. Pathogenic organisms, such as Listeria monocytogenes, Salmonella and Staphylococcus aureus have already been found in these products (Ferreira et al., 2006). L. monocytogenes are ubiquitous bacteria often present in meat products; its exclusion from foods is not easy. It has been isolated from meat in slaughterhouses (Jemmi, 1990; Työppönen, Markkula, Petaja, Suihko, \& Mattila-Sandholm, 2003) and meat products in different percentages (Colak, Hampikyan, Ulusoy, \& 
Bingol, 2007; Farber, Sanders, \& Johnson, 1989), although, generally, this microorganism does not exceed $10^{3} \mathrm{CFU} / \mathrm{g}$ in food products (Buchanan, Stahl, \& Archer, 1987; Ferreira et al., 2006). EC Regulation 2073-2005 requires that food products are negative for L. monocytogenes in $25 \mathrm{~g}$ samples whilst under the control of the manufacturer, and $<100 \mathrm{CFU} / \mathrm{g}$ in the marketplace.

There is increasing interest in the use of LAB as natural preservatives, due to the potential production of metabolites with antimicrobial activity such as organic acids (lactic and acetic), hydrogen peroxide, antimicrobial enzymes, bacteriocins and reuterin (Daeschel, 1989; Holzapfel, Geisen, \& Schillinger, 1995 Mataragas, Drosinos, \& Metaxopoulos, 2003). The use of LAB, which can grow in naturally contaminated meat products (Korkeala \& Mäkelä, 1989), as starter cultures in the manufacture of dry fermented sausages, is a common practice (Hugas \& Monfort, 1997; Lücke \& Hechelmann, 1987). Research on antimicrobial substances, mainly bacteriocins, produced by $\mathrm{LAB}$, has led to consideration of their use as natural preservatives in meat products (Aymerich, Hugas, \& Monfort, 1998; Castellano, Holzapfel, \& Vignolo, 2004; Dicks, Mellett, \& Hoffman, 2004; Hugas, 1998; Hugas, PagÈs, Garriga, \& Monfor, 1998). According to Nieto-Lozano, Reguera-Useros, Pel-aez-Martİnez, and De la Torre (2006) treatment with bacteriocins from a meat-derived $\mathrm{LAB}$, could help reduce the levels of $L$. monocytogenes in meats.

The aims of this present study were: (1) to test the antimicrobial activity of LAB isolated from "Alheiras" against $L$. monocytogenes and other selected pathogens; (2) to study the inhibitory effect of two bacteriocinogenic LAB strains on L. innocua (as a model for L. monocytogenes) by employing in situ assays in a sterilized model paste of "Alheiras", with the aim of evaluating their potential use as a biopreservatives.

Materials and methods

\section{Origin of LAB bacterial isolates}

Twenty-five gram of samples of "Alheiras" from different producers were added to $225 \mathrm{ml}$ of sterile buffered peptone water (Merck, Germany), and homogenized in a stomacher for $2 \mathrm{~min}$. Appropriate decimal dilutions were prepared in 1/4 -strength Ringer's solution (LabM, UK) for the enumeration of LAB on (i) de Man, Rogosa Sharpe Agar (MRS, LabM) and (ii) M17 agar (Merck) and incubated aerobically at $30^{\circ} \mathrm{C}$ for $72 \mathrm{~h}$. Colonies $(10 \%)$ were randomly picked from plates containing 10-100 colonies, sub-cultured into MRS (Merck) or M17 (Merck) broth depending on the medium of origin, incubated at $30{ }^{\circ} \mathrm{C}$ for $48 \mathrm{~h}$ and finally purified by streaking on plates of the respective medium. Gram-positive, catalase negative and oxidase negative isolates (Norris, Berkeley, Logan, \& O'Donnell, 1981) were selected and stored at $-80^{\circ} \mathrm{C}$ in MRS/M17 broth with 20\% (w/v) glycerol (Merck).

\section{Pathogenic and indicator strains}

L. innocua 2030c (PHLS), L. monocytogenes 54 (Escola Superior de Biotecnologia, UCP), S. aureus 29213 (ATCC), Escherichia coli 9001 (NCTC), E. coli 0157 (ESB, UCP), Enterococcus faecalis 29212 (ATCC), Salmonella Typhimurium (ESB, UCP) and Salmonella Enteriditis 05188 (NCTC) were used as target bacteria for the inhibitory effects of LAB. Bacteria were grown in TSB + YE $(6 \mathrm{~g} / \mathrm{l})$ $(\mathrm{LabM})$ at $30^{\circ} \mathrm{C}$ for $24 \mathrm{~h}$. All strains were stored at $-20{ }^{\circ} \mathrm{C}$ in TSB broth containing $30 \%(\mathrm{w} / \mathrm{v})$ glycerol, and sub-cultured twice before use in assays.

\section{Antibacterial activity}

TSB + YE agar plates were evenly spread with each of the target bacteria and drops $(10 \mu \mathrm{l})$ of LAB cultures, grown in MRS/M17 broth at $30^{\circ} \mathrm{C}$ for $24 \mathrm{~h}$, were spotted on the lawns of pathogens and incubated overnight at $30{ }^{\circ} \mathrm{C}$. Inhibition was recorded as positive if a translucent halo zone was observed around the spot. For the positive strains, characterization of the antimicrobial activity was performed according to Tomé, Teixeira, and Gibbs (2006). Culture broths were centrifuged (Rotina 35R, Hettich, Germany) at $3382 \times g$ for $15 \mathrm{~min}$, at $4{ }^{\circ} \mathrm{C}$. The clear supernatants were sterilized by membrane filtration $(0.2 \mu \mathrm{m}$, Corning Incorporated, Corning 431220, Germany). The $\mathrm{pH}$ of the cell-free supernatants was adjusted to 6.5 with $\mathrm{NaOH}(1 \mathrm{~N})$ and then treated with catalase (Sigma, Germany; $500 \mathrm{IU} \mathrm{ml}^{-1}$, sterile) and trypsin (Sigma; $0.1 \mathrm{mg} \mathrm{ml}^{-1}$, sterile), for $1 \mathrm{~h}$ at $37^{\circ} \mathrm{C}$. Cell-free supernatant, neutralized cell-free supernatant treated with catalase and neutralized cell-free supernatant treated with catalase and trypsin, were spotted against the target organisms. Lactobacillus sakei CTC 494 (CTC, IRTA Meat Technology Centre Collection Monells, Spain) was used as an anti-listerial reference strain.

\section{LAB identication}

Those cultures showing anti-listerial activity of a proteinaceous nature were identified using the API $50 \mathrm{CH}$ kit (bioMérieux, Marcy-1' Étoile, France) and analysed by APILAB PLUS software version 3.2.2 (bioMerieux).

\section{Anti-listerialactivityof2putatively-protectivecultures in a} sterilised paste of "Alheira"

Paste of "Alheira", before stuffing, was used in these experiments. This paste was produced by an industrial meat company and, on the day of its production, transferred to the laboratory at $4{ }^{\circ} \mathrm{C}$ and sterilized by autoclaving before being inoculated. The antagonistic effect of each of two strains of LAB (HA-6111-2 and HA-5692-3) on $L$. innocua was studied. A non bacteriocinogenic LAB strain (HA-3083-3), previously identified as $P$. pentosaceus, was used as control. The organisms were sub-cultured twice 
(24 h at $30{ }^{\circ} \mathrm{C}$ ) in $10 \mathrm{ml}$ MRS broth (HA-6111-2, HA-56923 and HA-3083-3) or TSB broth (L. innocua), using a $1 \% \mathrm{v} /$ $\mathrm{v}$ inoculum. An aliquot $(250 \mu \mathrm{l})$ of each bacterial suspension $\left(10^{9} \mathrm{CFU} / \mathrm{ml}\right.$ for $\mathrm{LAB}$ strains and $10^{6} \mathrm{CFU} / \mathrm{ml}$ for the $L$. innocua) was added to $25 \mathrm{~g}$ of sterilized paste of "Alheira" contained in stomacher bags. After assuring good mixing of the inoculum with the paste (manually massaging of the exterior of the bags), the samples were stored at $4{ }^{\circ} \mathrm{C}$ for $28 \mathrm{~d}$. At days $0,3,7,10,14,17,21,24$ and 28 of storage, inoculated paste samples were analysed for growth of the inoculated strains. The experimental conditions were: (1) uninoculated paste as control, (2) paste inoculated with $L$. innocua, (3) paste inoculated with HA-6111-2, (4) paste inoculated with HA-5692-3, (5) paste inoculated with HA-6111-2 and L. innocua, (6) paste inoculated with HA-5692-3 and L. innocua, (7) paste inoculated with HA3083-3, (8) paste inoculated with HA-3083-3 and L. innocua. Each trial was performed in triplicate.

\section{Microbiological sampling and analysis}

A $1 \mathrm{~g}$ sample was weighed aseptically into a sterile tube with $9 \mathrm{ml}$ of $1 / 4$-strength Ringer's solution and homogenized (by vortexing). Serial decimal dilutions in sterile $1 / 4$ -strength Ringer's solution were prepared and $20 \mu \mathrm{l}$ samples of the appropriate dilutions were spotted, in duplicate, on selective agar plates. Counts were performed on MRS incubated at $30^{\circ} \mathrm{C}$ for $72 \mathrm{~h}$ under microaerophilic conditions (LAB) and on PALCAM Agar (MERCK) incubated at $30{ }^{\circ} \mathrm{C}$ for $72 \mathrm{~h}$ (L. innocua). The selectivity of the growth media was checked with the catalase reaction on about $10 \%$ of the colonies grown on countable plates.

\section{Results and discussion}

Antibacterial activity

Two hundred and twenty six LAB strains, isolated from various "Alheiras", were screened for their antagonistic activity against: L. innocua, L. monocytogenes, S. aureus, E. coli, E. coli 0:157 (VT-ve), E. faecalis, S. typhimurium and $S$. enteriditis. Fourteen isolates were active against $L$. innocua and L. monocytogenes. Of these, 2 were also active against $S$. aureus and $E$. faecalis and 2 others were only active against $S$. aureus. Antimicrobial activity against the Gram-negative bacteria was not demonstrated by any of the strains investigated. This ineffectiveness of bacteriocin-producing LAB in inhibiting Gram-negative organisms is widely recognized (Hechard, Derijard, Letellier, \& Cenatiempo, 1992; Mathieu, Suwandhi, Rekhif, Milliere, \& Lefebvre, 1993; Stevens, Sheldon, Klapes, \& Klaenhammer, 1991). Using this screening method, the observation of an inhibition zone, may result from competition, lactic acid, bacteriocin or hydrogen peroxide production.

The inhibitory effect of the cell-free filtrates of each of the 14 positive isolates was evaluated. Antimicrobial activity was observed for 8 isolates, and only against $L$. innocua and L. monocytogenes. In order to test for possible bacteriocin production, cell-free extracts were subjected to neutralization, addition of catalase and digestion with trypsin. As shown in Table 1, only two strains demonstrated anti-listerial activity of a proteinaceous nature, where no halo was formed after incubation with trypsin. These 2 strains were Gram-positive cocci identified as Pediococcus pentosaceus $(99.9 \%$ for HA6111-2 and $99.6 \%$ for HA-5692-3) and had already been tested and confirmed for antimicrobial activity (Albano et al., 2007).

Anti-listerial activity of 2 putatively-bacterioc in producing cultures in a sterilised pasteof "Alheira"

In this study, it should be noted that L. innocua was used instead of $L$. monocytogenes since the two microorganisms show similar physiological properties with the difference that the former is not considered pathogenic. Moreover, some papers report a greater sensitivity of L. monocytogenes towards some antibacterial compounds than L. innocua

Table 1

Inhibitory activity $\left(25^{\circ} \mathrm{C}\right)$ of lactic acid bacteria against $L$. innocua $2030 \mathrm{c}$ and $L$. monocytogenes determined by a spot assay on MRS agar

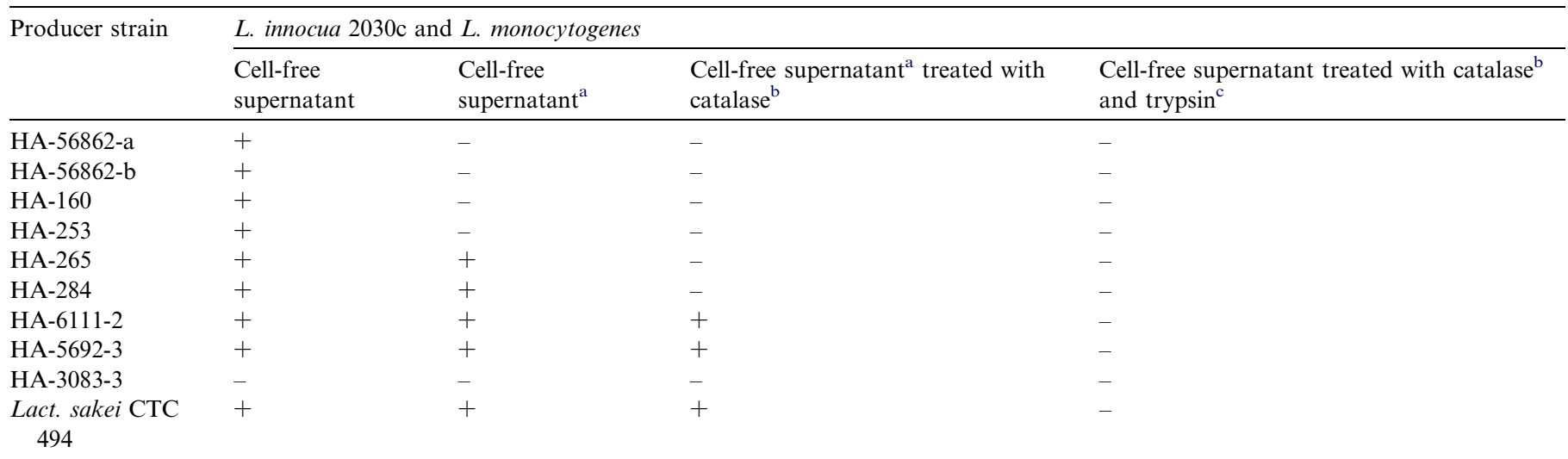

${ }^{\mathrm{a}}$ Adjusted to $\mathrm{pH} 6.5$.

b $500 \mathrm{IU} \mathrm{ml}^{-1}$

c $0.1 \mathrm{mg} \mathrm{ml}^{-1}$; + inhibition zone; - no inhibition zone. 
(Con, Ĝkalp, \& Kaya, 2001; Mataragas et al., 2003). As shown in Fig. 1a, after 10 days of storage, viable counts of the $P$. pentosaceus strains (HA-6111-2, HA-5692-3 and HA-3083-3) increased by $1 \log \mathrm{CFU} / \mathrm{g}$ during the initial 10 days of storage and remained constant until the end of storage of the "Alheira" paste both in the presence or absence of $L$. innocua. Previous studies also demonstrated that no influence in LAB populations was observed when inoculated with or without L. innocua (Alves, Lavrador, \& De Martinis, 2003; Alves, Martinez, Lavrador, \& De Martinis, 2006). In the presence of both bacteriocinogenic Pediococcus strains the initial concentration of L. innocua was maintained at $5 \times 10^{2} \mathrm{CFU} / \mathrm{g}$, whereas in their absence and in the presence of the control strain (HA-3083-3) counts increased to ca. $1 \times 10^{7} \mathrm{CFU} / \mathrm{g}$ after 28 days of incubation (Fig. 1b). Our study is in agreement with a previous study (Alves et al., 2003), where $L$. sakei 1 and $L$. monocytogenes cultures were inoculated in a model meat gravy system, and it was confirmed that in situ bacteriocin production played an important role in preventing growth of $L$. monocytogenes.

In industries which process animal based products, $L$. monocytogenes and other Listeria spp., mainly L. innocua, can contaminate most areas where raw materials are being processed and colonize equipment which are not made from stainless steel or are not disinfected properly (Mataragas et al., 2003). Overall, Listeria spp. are a major problem for this industry and although chemicals such as $\mathrm{NaNO}_{2}$ can inhibit Listeria and other pathogens in sausages, such substances may represent health risks for consumers and there is a constant demand for new preservative agents (Cleveland, Montville, Nes, \& Chikindas, 2001; Montville \& Winkowski, 1997). Some authors (De Martinis \& Freitas, 2003; Dicks et al., 2004; Työppönen et al., 2003) have suggested the use of bacteriocinogenic LAB as starter cultures, but the starter cultures proposed have not always been isolated from relevant fermented meat products. Those antimicrobial-active LAB originally isolated from traditional sausages are probably the best candidates for improving the microbiological safety of these foods. As they are adapted to the specific microenvironment they should be more competitive than LAB isolated from other sources. The use of bacteriocinogenic strains in food preservation is now being approved in several countries (Gomez, 1997) and bacteriociogenic LAB could be used as starter cultures in foods (Työppönen et al.,
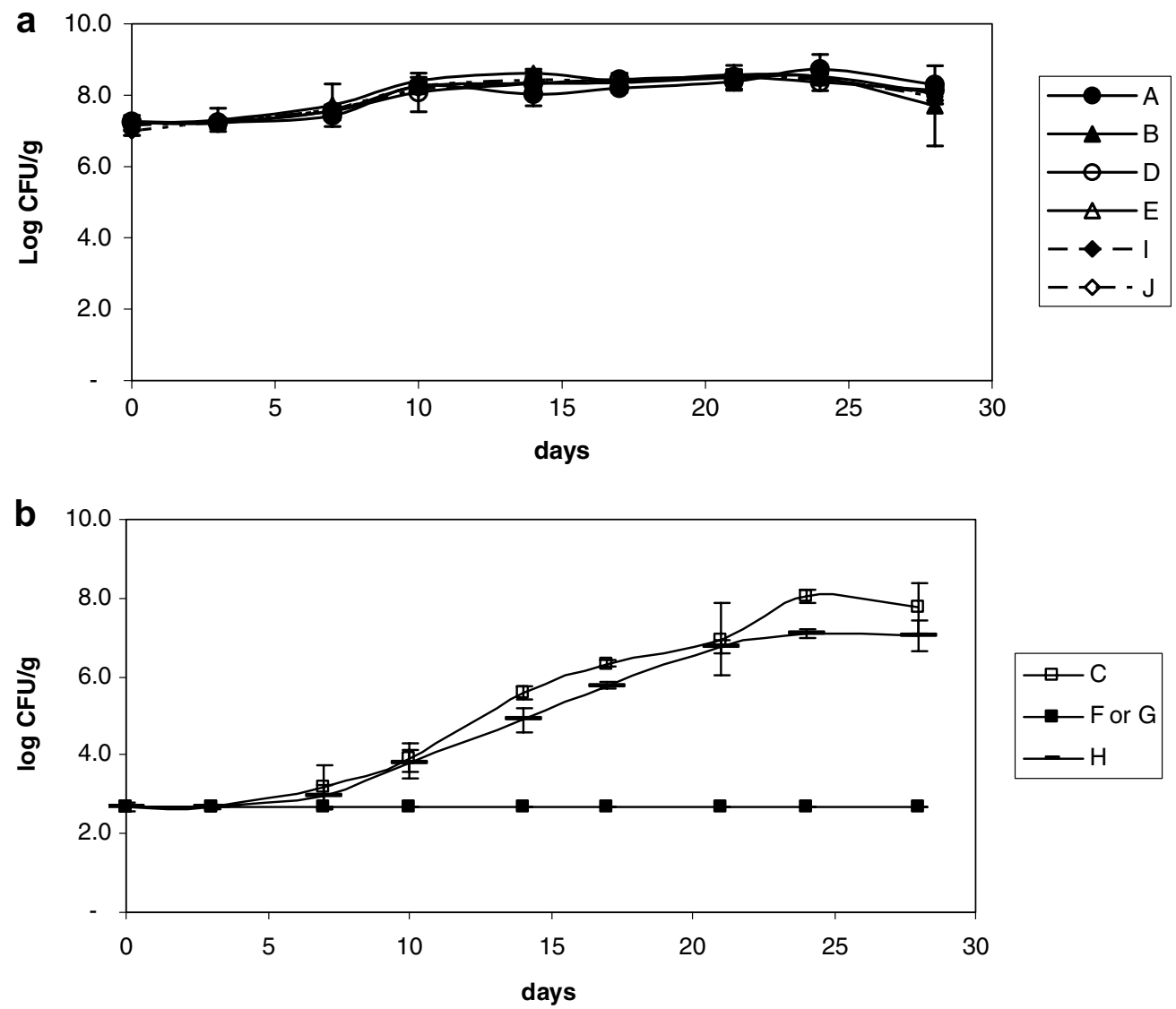

Fig. 1. (a) Growth of Pediococcus pentosaceus strains on "Alheira mass" during storage at $4{ }^{\circ} \mathrm{C}$ in the absence and presence of $L$. innocua (b); Growth of L. innocua on "Alheira mass" during storage at $4{ }^{\circ} \mathrm{C}$ in the absence and presence of LAB strains. (A (-) - HA-6111-2 strain; B (A) - HA-5692-3 strain; C $(\square)$ - L. innocua; D $(\bigcirc)$ - HA-6111-2 strain + L. innocua; E $(\triangle)$ - HA-5692-3 strain + L. innocua; F and G $(\square)-L$. innocua + HA-6111-2 strain or HA5692-3 strain, respectively; H $(-)-$ non bacteriocinogenic strain + L. innocua; I $\diamond)-$ non bacteriocinogenic strain $+L$. innocua; J $(\diamond)-$ non bacteriocinogenic strain). The error bars indicate the mean standard deviations for the data points. 
2003). These antibacterial compounds may be weapons to use against the growth of pathogenic microorganisms. The possibility of using the two bacteriocinogenic Pediococcus strains described in this study as protective cultures in the production of "Alheiras" and also as 'natural' inhibitors of undesirable microorganisms colonising processing surfaces, would certainly improve the safety of these products.

\section{Acknowledgements}

This work received financial support via project POCTI/ AGG/39587/2001 Fundação para a Ciência e Tecnologia (FCT)/Fundo Europeu Desenvolvimento Regional (FEDER). Financial support for author H. Albano was provided by PhD fellowship, SFRH/BD/13161/2003 (FCT).

Eurofumeiro - Sociedade Industrial de Transformação Tradicional de Carnes, Lda. kindly supplied the "Alheira" pastes.

\section{References}

Albano, H., Todorov, S. D., Van Reenen, C. A., Hogg, T., Dicks, L. M., \& Teixeira, P. (2007). Characterization of two bacteriocins produced by Pediococcus acidilactici isolated from "Alheira", a fermented sausage traditionally produced in Portugal. International Journal of Food Microbiology, 10, 239-247.

Alves, V. F., Lavrador, M. A. S., \& De Martinis, E. C. P. (2003). Bacteriocin exposure and food ingredients influence on growth and virulence of Listeria monocytogenes in a model meat gravy system. Journal of Food Safety, 23, 201-217.

Alves, V. F., Martinez, R. C. R., Lavrador, M. A. S., \& De Martinis, E. C. P. (2006). Antilisterial activity of lactic acid bacteria inoculated on cooked ham. Meat Science, 74, 623-627.

Aymerich, M. T., Hugas, M., \& Monfort, J. M. (1998). Review: bacteriocinogenic lactic acid bacteria associated with meat products. International Food Science and Technology, 4, 141-158.

Buchanan, R. L., Stahl, H. G., \& Archer, D. L. (1987). Improved planting media for simplified quantitative detection of Listeria monocytogenes in foods. Food Microbiology, 4, 269-275.

Castellano, P. H., Holzapfel, W. H., \& Vignolo, G. M. (2004). The control of Listeria innocua and Lact. sakei in broth and meat slurry with the bacteriocinogenic strain Lactobacillus casei CRL 705. Food Microbiology, 21, 291-298.

Cleveland, J., Montville, T. J., Nes, I. F., \& Chikindas, M. L. (2001). Bacteriocins: safe, natural antimicrobials for food preservation. International Journal of Food Microbiology, 71, 1-20.

Colak, H., Hampikyan, H., Ulusoy, B., \& Bingol, E. B. (2007). Presence of Listeria monocytogenes in Turkish style fermented sausage (sucuk). Food Control, 18, 30-32.

Con, A. H., Gôkalp, H. Y., \& Kaya, M. (2001). Antagonistic effect on Listeria monocytogenes and Linnocua of a bacteriocin-like metabolite produced by lactic acid bacteria isolated from sucuk. Meat Science, 59, 437-441.

Daeschel, M. A. (1989). Antimicrobial substances from lactic acid bacteria for use as food preservatives. Food Technology, 43, 164-167.

De Martinis, E. C. P., \& Freitas, F. Z. (2003). Screening of lactic acid bacteria from Brazilian meats for bacteriocin formation. Food Control, 14, 197-200.

Dicks, L. M. T., Mellett, F. D., \& Hoffman, L. C. (2004). Use of bacteriocin-producing starter cultures of Lactobacillus plantarum and Lactobacillus curvatus in production of ostrich meat salami. Meat Science, 66, 703-708.
Farber, J. M., Sanders, G. W., \& Johnson, M. A. (1989). A survey of various foods for the presence of Listeriaspecies. Journal of Food Protection, 52, 456-458.

Ferreira, V., Barbosa, J., Vendeiro, S., Mota, A., Silva, F., Monteiro, M. J., et al. (2006). Chemical and microbiological characterization of alheira: a typical Portuguese fermented sausage with particular reference to factors relating to food safety. Meat Science, 73, $570-575$.

Gomez, S. (1997). Evidence for bacteriocin-like substances produce by a new strain of Streptococcus sp., inhibitory to Gram-positive foodborne pathogens. Research in Microbiology, 148, 757-766.

Hechard, Y., Derijard, . B., Letellier, F., \& Cenatiempo, Y. (1992). Characterization and purification of mesentericin Y105, an antiListeria bacteriocin from Leuconostoc mesenteroides. Journal of General Microbiology, 138, 2725-2731.

Holzapfel, W. H., Geisen, R., \& Schillinger, U. (1995). Biological preservation of foods with reference to protective cultures, bacteriocins and food-grade enzymes. International Journal of Food Microbiology, 24, 343-362.

Hugas, M. (1998). Bacteriocinogenic lactic acid bacteria for the biopreservation of meat and meat products. Meat Science, 49, S139-S150.

Hugas, M., \& Monfort, J. M. (1997). Bacterial starter cultures for meat fermentation. Food Chemistry, 59, 547-554.

Hugas, M., Pagès, F., Garriga, M., \& Monfor, J. M. (1998). Application of the bacteriocinogenic Lact. sakei CTC494 to prevent growth of Listeria in fresh and cooked meat products packed with different atmospheres. Food Microbiology, 15, 639-650.

Jemmi, T. (1990). Epidemiological studies on Listeria spp. in slaughterhouses. Fleischwirtschaft, 70, 1448-1450.

Korkeala, H., \& Mäkelä, P. (1989). Characterization of lactic acid bacteria isolated from vacuum-packed cooked ring sausages. International Journal of Food Microbiology, 9, 33-43.

Lücke, F. K., \& Hechelmann, H. (1987). Starter cultures for dry sausages and raw ham. Fleischwirtschaft, 67, 307-314.

Mataragas, M., Drosinos, E. H., \& Metaxopoulos, J. (2003). Antagonistic activity of lactic acid bacteria against Listeria monocytogenes in sliced cooked cured pork shoulder stored under vacuum or modified atmosphere at $4 \pm 2{ }^{\circ} \mathrm{C}$. Food Microbiology, 20, 259-265.

Mathieu, F., Suwandhi, S., Rekhif, N., Milliere, J. B., \& Lefebvre, G. (1993). Mesenterocin 52, a bacteriocin produced by Leuconostoc mesenteroides ssp. mesenteroides FR 52. Journal of Applied Bacteriology, 74, 372-379.

Montville, T. J., \& Winkowski, K. (1997). Biologically based preservation systems and probiotic bacteria. In M. P. Doyle, L. R. Beuchat, \& T. J. Montville (Eds.), Food microbiology: Fundamentals and frontiers (pp. 557-576). USA: ASM Press.

Nieto-Lozano, J. C., Reguera-Useros, J. I., Peàez-Martìnez, M. C., \& De la Torre, A. H. (2006). Effect of a bacteriocin produced by Pediococcus acidilactici against Listeria monocytogenes and Clostridium perfringens on Spanish raw meat. Meat Science, 72, 57-61.

Norris, J. R., Berkeley, R. C. W., Logan, N. A., \& O'Donnell, A. G. (1981). The genera Bacillus and Sporolactobacillus. In M. P. Tarr, H. Stolp, H. G. Tr, per, A. Balows, \& H. G. Schlegel (Eds.), The prokaryotes: A handbook on habitats, isolation and identification of bacteria (pp. 1711-1742). Berlin, Germany: Springer.

Stevens, K. A., Sheldon, B. W., Klapes, N. A., \& Klaenhammer, T. R. (1991). Nisin treatment for inactivation of Salmonella species and other Gram-negative bacteria. Applied Environmental Microbiology, 57, 3613-3615.

Tomé, E., Teixeira, P., \& Gibbs, P. A. (2006). Anti-listerial inhibitory lactic acid bacteria isolated from commercial cold smoked salmon. Food Microbiology, 23, 399-405.

Työppönen, S., Markkula, A., Petaja, E., Suihko, M. L., \& MattilaSandholm, T. (2003). Survival of Listeria monocytogenes in North European type dry sausages fermented by bioprotective meat starter cultures. Food Control, 14, 181-185. 